
$\angle$ Research Square
Preprints are preliminary reports that have not undergone peer review.
They should not be considered conclusive, used to inform clinical practice, or referenced by the media as validated information.

\title{
Developing Research Competence of Teachers as a Way of Increasing Competitiveness of HEls in Kazakhstan
}

\author{
Mariya Begunova ( $\square$ bmariyas@mail.ru ) \\ Soochow University - Dushu Lake Campus https://orcid.org/0000-0002-4316-1125 \\ Xu Qingyu \\ Soochow University - Dushu Lake Campus
}

\section{Regular Article}

Keywords: Research competence of a teacher, competitiveness of a HEl, higher education, ways to increase competitiveness.

Posted Date: February 4th, 2021

DOI: https://doi.org/10.21203/rs.3.rs-165327/v1

License: () (7) This work is licensed under a Creative Commons Attribution 4.0 International License. Read Full License 


\section{Abstract}

The present article shows the findings of a basic quantitative research of the teachers' research competence and its influence on higher educational institutions' (hereafter: HEI) competitiveness on the sample of Kazakh University of International Relations \&World Languages after Ablaikhan (hereafter: KazUIR\&WL). Using the method of questionnaire, the study investigates the level of satisfaction of the students and parents with the education quality in KazUIR\&WL, their needs and expectations, as well as shows the linkage between teachers' research competence and the quality of education. The research involves 19 teachers, 70 students and 70 parents, who present their opinions by answering both open-ended and close-ended questions. The present research is inductive non-experimental and helps build a strong theoretical platform for generating further research questions. The main purpose of the research is mostly an assessment of the current situation in teaching English in Kazakhstan, with elements of evaluation and description. In this aspect, the current study can become a good scientific background for generating further research ideas in the sphere of education, linguistics, methodology, history, foreign culture studies and others. The method used in the present research is the method of questioning.

\section{Introduction}

The process of globalization has touched many spheres of our life, including education. The more developed the country, the more emphasis it puts onto education and its role in economic and social development (Leko-Šimić \& Štimac, 2012). Nowadays, many students all over the world have a wide choice of options to get degree both in their motherland and abroad. Despite a big range of opportunities to choose a HEl, the growing number of students in Kazakhstan results in a lower probability to win scholarship in a Kazakhstani university, so the number of self-supported students is growing year by year. Today, most of the school-leavers in Kazakhstan choose self-paid study. First of all, it's connected with a limited number of scholarship in Kazakhstan.

According to the statistics on 2016/2017 academic year, the general number of students in Kazakhstan was 477074 people. Among them, 126564 people were awarded scholarship (26,5\%), 13564 people (2,9\%) were studying on a special state order (with a purpose of working at a certain state position after graduation) and $336813(70,6 \%)$ students on self-paid basis (Serikbayev, 2017). This fact leads to higher public expectations and demands for the quality of education. Alongside with other types of services, universities function as market-oriented companies providing their goods to customers. In the modern economy higher education institutions (hereafter, HEls) are treated equally like any other companies across various industries, and economic efficiency is getting a primary task to be achieved (Kireeva, Slepenkova, Shipunova \& Iskandaryan, 2018).

As the results, HEls constantly need to struggle for more clients, while clients themselves are ready to pay money for a high-quality education. Here we can underline the importance of teaching quality. Why we touch upon the topic of teaching is because it shows quality of education and thus, it directly affects the status of a school or university, therefore, increasing its reputation and competitiveness. In the present article, we will focus on higher educational institutions. In order to understand how to increase a university status and competitiveness, it seems logical to pay attention to the features of a successful university. According, to Forbes, one of the factor of successful university is "A combination of freedom, autonomy and leadership. World-class universities thrive in an environment that fosters competitiveness, unrestrained scientific inquiry, critical thinking, innovation and creativity. Institutions that have complete autonomy are also more agile, because they aren't bound by clunky bureaucracies and externally imposed standards. As a result, they can manage their resources efficiently and quickly respond to the demands of a rapidly changing global market" (Forbes, 2009).

Educational management in Kazakhstan wants to increase HEls' competitiveness and, thus, get potential customers' trust. Customers' satisfaction will pay a key role in this process. One of the ways to improve HEls' competitiveness is to invest into their teaching personnel by developing their research competence.

Research questions:

1. What ways of increasing HEls' competitiveness exist?

2. How does teaching quality affect the competitiveness of a university?

3. What are the peculiarities of conducting research for teachers?

4. What is the connection between teaching quality and research competence of a teacher?

Problem of research: students have a wide choice of options for their studies, so HEls need to attract their attention by increasing competitiveness.

Significance of the Study

The current research work provides good and solid scientific background for generating new ideas in the sphere of research competence of teachers. It illustrates the current picture of the situation with education in one of the biggest universities of Kazakhstan.

Object of research: on the sample of KazUIR\&WL, to consider research competence of teachers as a way to increase HEls' competitiveness.

\section{Literature Review}

\subsection{The role and the functions of a modern teacher in HEls in Kazakhstan}

The recent reorientation of educational principles and results switches from such notions as 'education', 'upbringing', 'culture' to the concept of 'studentcentered competence approach'. Therefore, one of the urgent tasks of education is to teach schoolchildren how to search and process information through the implementation of independent research work carried out within the competence-based approach. This task can be solved by purposefully developing the research competence of schoolchildren, contributing to the development of their motivation to work, strengthening their curiosity and need for knowledge, forming a creative personality, expanding their overview and mental outlook and overcoming difficulties with great perseverance.

Page $2 / 11$ 
The collection's preface was written by the famous historian-archivist M. Zh. Hasanal, who pointed out the following: "The universality of language as a communication and its national characteristics make it a unique phenomenon in human history. The history of each language is inseparable from the history of those who own it. The formation of a unified national language and the status of the country and prosperity is closely related, and any change related to its development or the dynamics of the decline of the country can only affect the state of language. (Hasanal, 2010, p. 6). These ideas are offered by some of the Kazakhstani scientists and methodologists. As it has been mentioned by Kunanbayeva (2005), modern education system should be oriented to the learners' individual willingness to look for knowledge, rather than to get them in the full and completed form transmitted by the teacher during the class, as well as being taught alongside with the culture of a target country. In accordance with this idea, it becomes possible to say that education becomes more effective, as well as rational and practical, and will be more creative and productive.

So, what is really essential for a modern foreign language teaching? To answer this question, we need to understand the key features that characterize directly the system of foreign language education. The specificity of foreign language education is obvious due to a number of factors that Gal'skova (2003) defined as follows: socio-economic and political factors, socio-educational, socio-cultural, methodological, and individual factors. Today the personality with the ability to actively engage in communication in a foreign language, owning the knowledge of both native and target cultures, and who is therefore capable of culturally sensitive partners in dialogue is highly demanded. In other words, modern teachers need to own intercultural communicative competence.

Therefore, the model of professional competences of a modern teacher at university level can be presented as follows:

Professionally-identifying competence, which include theoretical and predictive, reflexive and professionally-developing subcompetences;

International communicative competence (hereafter: ICC) with its communicative, interpretative, contextual, modeling and creativitydeveloping subcompetences;

Research competence, which implies searching, analytical, creative, modeling, diagnostic, experimental and metalinguistic subcompetences (Fig. 1).

According to Badley and Habeshow (1991), in the process of technological development, the role of a teacher is transferred to a 'manager of the classroom'. As a manager of learning the HE teacher will have to be a flexible, general educator, committed to a multi-discipline approach to learning, to lifelong education and training both for himself and for those who will rely upon his guidance for their learning (Badley \& Habeshow, 1991).

Thus, we can see that the role and the functions of a teacher in HE have been changed and modified in accordance with the new standards and demands of the society.

\subsection{The ways of increasing competitiveness of HEIS}

Today, living in the world of marketing, we cannot deny its influence on every sphere of our life, including education. Universities, as educational institutions, play a vital role in the development and improvement of the society, contributing to the welfare of citizens. Considering the social responsibility of universities with a large number of stakeholders (students, institutions, government, employees, companies, local community, etc.), university in its daily management is also considered a corporate entity, which set up strategic plans and practices, an essential process to achieve its success in the long term. (Ramos, LlinásAudet \& Barrena Martinez, 2017).

One of the reasons for that is the rapid leap in the number of private sector universities and its dominance over the public sector. Here we see that the role of 'students' also changes to 'clients', who pay money and want a result - that is knowledge. Thus, HEls have to compete with each other in order to attract more potential customers.

When a university seeks to be competitive, it needs to rethink whether its activities meet the needs of its stakeholders and perhaps need to build stronger strategic relationships with its stakeholders to respond to changes in the education sector (Dima, Vasilache, Ghinea \& Agoston, 2013).

Of course there is a bunch of ways of increasing popularity of a company, and the first thing that we can think of is advertising.

According to the article written by Kazakhstani scholars Sayanbek and Serikbekuly, there are four main directions of increasing a university competitiveness:

- The creation and maintenance of university website

- Advertising on the Internet

- Posting information about the services of an educational organization on industry portals

- University blogging (Sayabek, Ziyadin \& Serikbekuly, Askhat, 2020).

The major challenges in higher education today are: decreasing quality due to inadequate models of teaching process evaluation, inadequate application of existing quality control mechanism, favorization of general education, devaluation of liberal model of education, plethora of information and fragmentation of knowledge, commercialization of scientific projects, etc. (Gajić, 2010, p.44-46). All these challenges put increasing pressure on traditional universities and at the same time create favorable environment for transformation of higher education institutions form faculty-centered into market-driven organizations. From this fact arises the need for application of marketing concept in higher education institutions (Leko-Šimić \& Štimac, 2012).

So, the root of the issue is - the quality of education. Where there is education of a high level - there are clients (students). If we think of the quality of education, many students and parents would say - it's a mainly the quality of teaching. The corporate model affects the administrative structure of the 
college as well as what takes place in the classroom (Polet, 2018).

Beneficiaries of the education service are constantly testing and evaluation its quality. It can be said that the higher level of development put stricter rules and expectations on education service quality (Funda, 2008, p.9,13). Besides, economic and cultural globalization has created new challenges for the higher education system since it requires global openness and knowledge exchange since the labor market is increasingly becoming liberalized (Leko-Šimić \& Štimac, 2012).

Thus, in order to improve educational quality, we must pay attention to teaching staff and develop their teaching abilities. Universities of Kazakhstan should invest into their teachers by organizing professional training, seminars and lectures for free or at the low cost. One of the characteristics of a professional teacher in university level - is a developed research ability.

It goes without saying that universities with recognizable names and good reputation are more likely to be highly competitive. According to BBC news, another important factor of increasing competitiveness is "citations per faculty", which focuses on the level of research in universities, calculated in terms of the number of times research work is cited by other researchers (BBC News, 2014).

Thus, we can consider teaching quality as a direct factor affecting the quality of education and, hence, one of the way of improving the competitiveness of a HEI.

\subsection{Research in the sphere of teaching}

Research competence is the basis for the development of intellectual, communicative, design skills, develops critical thinking, creative abilities of the teacher. Teachers are researchers. They collect enormous amounts of data each day, and they rapidly evaluate and make decisions based on this data. Some of this work is numerical, but much is qualitative. Teachers may be second only to doctors in doing this. What teachers are not good at is doing anything formal with this data (Whitman \& Kelleher, 2017).

Nowadays, in Kazakhstan in the sphere of higher education we can roughly talk about two types of teachers: academicians and practicians. If academicians mainly deal with theoretical disciplines and their professional activity is automatically linked to conducting research, then with practicians it seems quite dissimilar. Teachers of practical disciplines, such as language teachers or methodology teachers, should understand that for them the purpose of doing research differs from those of theoretical disciplines teachers.

According to Hairon, "The objective in academic research is to produce new knowledge but for most teachers doing research, the purpose is to improve practice while being informed by theory at the same time. When they do literature review, they don't have to be exhaustive. The purpose is to look for literature that pertains specifically to the classroom teaching strategy that they wish to try or explore (Hairon, 2020)."

In addition, the research competence of a University Teacher should be understood as a set of knowledge and skills necessary for the implementation of research activities. Research competence should be attributed to the key competencies of the teacher, since its presence is crucial for professional pedagogical activity, the development of pedagogical skills and professionalism. Research knowledge and skills it is one of the most striking characteristics of the level of professional maturity of a teacher.

If to talk about teachers-practicians and the role of research in their professional activity, it should be noted that the research competence is directly related to the effectiveness of teaching the university level. In the market of educational services, one of the main conditions for ensuring the competitiveness of higher education institutions is the level of professional competence of a University Teacher, which determines the quality of training of future specialists. In a highly competitive environment, higher education is implementing innovative educational technologies designed for competent teachers, whose development is hindered by the presence of certain problems. The research position, according to Obuhov A.S., it is not only that which is actualized in the situation of uncertainty, but also the position, on the basis of which a person needs to get into these situations, to find them; And after finding a situation that requires research activity - to pass the main stages of the study in succession. (Obuhov, 2006, p. 6).

Summarizing various approaches to defining the essence of research competence, we note that there is no unambiguous interpretation of this concept. On the one hand, research competence should be considered as a component of professional competence, on the other - as an integral component of general and professional education. Therefore, research competence is an important tool for a university teacher and can be considered as the structural unit of his mental activity (Slastenin, 2002). The following signs of the teacher-researcher can be distinguished as follows:

- ability to observe, analyze and explain observational data, to separate significant facts from non-essential;

- ability to conduct an experiment (staging, explanation and presentation of the results);

- ability to carry out an active search at its individual stages;

- understanding of the structure of theoretical knowledge;

- mastery of general scientific ideas and principles;

- ability to highlight the main thing in complex natural phenomena, abstract, analyze and generalize the material;

- knowledge of the methods of scientific knowledge;

- ability to consider phenomena and processes in correlation, to reveal the essence of objects and phenomena, to see their contradictions. 
On the basis of the mentioned above characteristics of a teacher-researcher, it seems logicalto define the abilities (or sub-competences) which all together can form Research Competence of a Teacher as follows:

1. Ability to analyze the current situation in education Reviewing the available literature - here we take, receive and process the information from different types of sources, like scientific articles, theses written by others, websites of different sorts and others.

2. Ability to define gaps and problems to be researched Identification of the problem - is the initial stage of any research. It suggests finding a contradiction (or a problem) which prevents the development of the process. This problem can be discovered after having the practical experience in the field or gaining some theoretical information. For example, scholars who have been teaching English for a certain period of time, may realize at one stage that something is not working anymore or some methods are more or less effective etc. Or they may feel that the final teaching result (university graduates and their skills) does not fully match the society needs. Thus, it leads to a contradictory situation. As the result, the scholars may need to find a proper solution to this problem or the contradiction. And here we come to emphasizing the hypothesis. Formulating a question - a stage when we should come up with a question or a 'gap' in the topic of research which demands our careful exploration.

3. Ability to set aims and objectives - generating the main goal of the work and research questions, defining your expectations and outcomes.

4. Research methods acquisition - Selecting an appropriate research design;

5. Critical thinking ability - Interpretation of findings - in accordance with what you knew from different sources mentioned above, a scholar, who is in charge with the research, must try to formulate a personal vision and understanding of the existing problem, as well as come up with some possible solution or solutions to it.

6. Ability to use IT in the classroom - which helps to make a lesson more innovative and effective

7. Creative ability - allows to diverse classes by trying new teaching methods and techniques and involves more students into learning process.

Researching teachers create school and classroom environments in which there are researching students. Students and teacher work together to ask (not just answer) questions, and to pose (not just solve) problems. By becoming question-askers and problem-posers, students and teachers work together to construct curriculum from their context and lived experiences, rather than just receive preselected and predigested information that will appear on a test. And in working to construct meaningful curriculum together, you and your students engage in professional development and classroom learning activity that offers hope for the future in these trying education times (Watson, 2013). In this way, we cannot deny the importance of research in the teaching process.

\section{Gaps \& Conceptual Framework}

\subsection{Conducting research as one of the functions of a teacher at university level}

In the market of educational services, one of the main conditions for ensuring the competitiveness of higher education institutions is the level of professional competence of the University teacher, which determines the quality of training of future specialists (Kunanbayeva, 2005).

In a general sense, research competence refers to the ability of a specialist in a particular field to successfully solve the tasks of professional activity according to set standards. Competence is what a specialist has achieved. The components of a specialist's research competence are knowledge, skills, and professionally significant personal qualities that together ensure their ability to successfully perform their work (Kunanbayeva, 2005).

Kunanbayeva (2010) suggests seven key elements of the Research Competence of a teacher:

Searching - allows to look for and select a sufficient information for a certain topic;

Analytical - shows a teacher's ability to select and analyze information, in order to choose the needed one;

Creative - demonstrates the ways a teacher uses to make the lesson more diverse and full of different techniques and activities;

Modeling - helps to formulate a topic, a problem, objectives and goals;

Diagnostic - explores gaps and shortages in a certain sphere;

Experimental - tastes a hypothesis in practice (classroom);

Metalinguistic - shows a teacher's scientific speech-craft.

Thus, we can draw a linkage between the above-mentioned elements and the sub-competences of Research competence suggested by us (Fig. 2).

\subsection{Teaching quality as a way to increase competitiveness of a university}

Since traditionally universities have conceived their task as limited to the elaboration and transfer of disciplinary knowledge, it is not surprising that many academics are not used to considering the issues of teaching/learning methods and are not familiar with (or even diffident towards) the vocabulary and the conceptual framework used to describe and classify those methods" (Požarnik, Barica, 2009). The quality of teaching connected to the competencies of teaching staff is slowly getting its place among quality criteria (Požarnik, Barica, 2009).

The present study is considered inductive, since it derives a general result from a concrete element. In our case, it is 'Research competence of a teacher' as a concrete element, which can result in general improvement of a HEl's competitiveness. 
In this way, we can assume that the development of research competence of a teacher is one of the possible ways of increasing the level of competitiveness of a university (Fig. 3).

Based on the suggestions given by Sayanbek \& Serikbekuly (2020) and Gajić, (2010), we can conclude that nowadays there are two main vectors on increasing the competitiveness of a university:

To provide sufficient information to potential customers

To increase teaching quality by changing and correction of the models of teaching (Fig. 4).

\section{Research Design}

Kazakh University of International Relations and World Languages after Ablaikhan (KazUIR\&WL) is a private sector university and one of the biggest organizations in Kazakhstan. Since it has recently turned to private sector, it now aims to attract more students and increase its reputation. Thus, the survey is designed to get the opinions of three stakeholders of the university as a corporation - students, teachers and parents, in order to check their satisfaction with the quality of education. The data is mainly quantitative, non-experimental and descriptive in nature, however, to check the research competence of teachers, I use open-ended questions. After collecting the data, all the information will be measured and converted to numerical system.

\subsection{Population of the survey}

The participants of the survey are students of the 1 and 2 academic year with the major "International Relations", teachers of English and lecturers in Sociology and History of language, as well as parents. The data will be analyzed with Excel and Z-test.

In order to check the ability of teachers of KazUIR\&WL of conducting research, the questionnaire has been created (VanGundy, 2005). The questionnaire is composed of 20 questions on research topic, which are aimed at checking the above-mentioned 7 abilities of teachers (Crystal, 2006).

The research covered the following population:

1. 160 students of the 1 and 2 academic year with the major "International Relations" of KazUIR\&WL;

2. 20 teachers of English and lecturers in Sociology and History of language from the Basic Department of International Relations;

3. 100 parents.

\subsection{Sampling of the study}

Based on the modified formula suggested by Cochran (1963), we calculated the following sample size: to the population of 160 students, the sample size is 113; to the population of 20 teachers, the sample size is 19; to the population of 100 parents, the sample size is 79 . Thus, we operated the following information:

1. 113 students of the 1 and 2 academic year with the major "International Relations" of KazUIR\&WL (70\%);

2. 19 teachers of English and lecturers in Sociology and History of language from the Basic Department of International Relations (95\%);

3. 79 parents $(79 \%)($ Table 1$)$.

Table 1

Total response ratio of the participants

\begin{tabular}{|llll|}
\hline KazUIR\&WL & Teachers & Students & Parents \\
\hline General number of participants & 20 & 160 & 100 \\
\hline Factual number of participants & 19 & 113 & 79 \\
\hline Total number of responces & 19 & 70 & 70 \\
\hline Total response ratio & $100 \%$ & $62 \%$ & $88 \%$ \\
\hline
\end{tabular}

\subsection{Analysis and interpretation of data}

The data collected through the method of survey, which was composed of 10 close-ended questions for students and parents and 20 open-ended questions for teachers. The data was carefully collected and analyzed with Z-test, and later on all the numerical data was calculated and presented in tables.

There were two types of survey: one was composed of 10 closed-ended questions and was offered to answer by students and their parents. The questions were mainly aimed at checking the level of satisfaction of students and parents with the present situation in education, as well as finding out their needs and preferences as customers. The second survey consisted of 20 open-ended questions and was distributed to teachers (lecturers and practitioners), and was 
mainly directed to characterize the level of research competence development of teachers on the sample of KazUIR\&WL. The survey highlighted such points as teachers' ability to analyze the current situation in education, their ability to set aims and objectives and awareness of research methods.

\section{Results And Finding}

\subsection{The results of the first survey}

After careful data analysis, the results of the both surveys were calculated. Altogether, 70 students and 70 parents took part in the survey. There were 10 closeended questions, which aimed at four main directions: university's reputation, teaching quality, administration work and learning opportunities (National ranking of the best universities of Kazakhstan, 2020).

According to the results, it can be noted that a half of the students and more than $40 \%$ of parents see teaching quality as the main part of a successful and competitive university (Table 2).

Table 2

General results of the first survey

\begin{tabular}{|lllll|}
\hline Responses & University reputation & Teaching quality satisfaction & Administration work satisfaction & Learning opportunities \\
\hline Students & $0(0 \%)$ & $35(50 \%)$ & $13(19 \%)$ & $22(31 \%)$ \\
\hline Parents & $11(16 \%)$ & $29(41 \%)$ & $5(7 \%)$ & $25(36 \%)$ \\
\hline Overall $\%$ & $8 \%$ & $45.7 \%$ & $12.8 \%$ & $33.5 \%$ \\
\hline
\end{tabular}

\subsection{The results of the second survey}

In the second survey, 19 teachers and lecturers of the Basis department of International Relations were invited to participate. The survey had 20 open-ended questions with its aim to check teachers' research competence and mainly focused on the following directions: ability to observe, analyze and explain observational data, to separate significant facts from non-essential, ability to conduct an experiment, ability to carry out an active search at its individual stages, understanding of the structure of theoretical knowledge, mastery of general scientific ideas and principles, ability to highlight the main thing in complex natural phenomena, abstract, analyze and generalize the material, knowledge of the methods of scientific knowledge, the ability to consider phenomena and processes in correlation, to reveal the essence of objects and phenomena, to see their contradictions (Slastenin, 2002).

The next diagram visually shows the results of the survey:

Diagram 1. General results of the survey for teachers

\section{Discussion \& Recommendations}

According to DeWitt (2019), there are four main reason why teachers do research and why they don't. Among positive factors are the following:

1. The research they do fits the content they teach;

2. Doing research helps them promote their activity in social media (e.g. blogging);

3. Research findings and results can easily be checked and verified in practice (they can also be changed or corrected easily, if needed);

4. They have to conduct research, because it is a demand of their workplace.

As for the negative elements which affect the process of doing research, the next points can be mentioned:

1. Teachers may not always be sure that it is relevant to their teaching content;

2. They already do it perfectly, so they don't have to do it again;

3. They don't have enough time;

4. It's too complicated (DeWitt, 2019).

One more idea about the retrograde development of research in teaching was expressed by MacLellan (2016). He insists on the idea that teachers and research belong to different groups, while research papers are mainly written for researchers. So, it might be challenging for teachers to read research papers and generate their own research ideas (MacLellan, 2016).

It can be clearly noticed that in the present research paper the main focus is stressed on teachers' research competence, but it doesn't aim to promote the idea of inseparability of teachers and researchers. Teachers and researchers usually pursue different aims when conducting research. For researcher the main goal of the process is to come up with new findings, while for teachers it's mainly to improve their teaching style. It can also be underlined that research competence occupies one of the key important positions in the professional activity of an English language teacher, especially when we talk about university level.

According to British Educational Research Association (2014), there fur main ways in which research can contribute the teaching process:

- The content of teaching programmes may be informed by research-based knowledge;

Page $7 / 11$ 
- Research can be used to inform the design and structure of teacher education programmes;

- Teachers and teacher educators can be equipped to engage with and be discerning consumers of research;

- Teachers and teacher educators may be equipped to conduct their own research, individually and collectively, to investigate the impact of particular interventions or to explore the positive and negative effects of educational practice (British Educational Research Association, 2014).

At first sight, it can seem confusing or misleading that talking about teaching competences, we mention research competence. Because the concept of research is usually associated with science and scholars, but not English language teachers. But the present research clearly shows us that research competence is very important for a teacher, especially at university level. It helps teachers grow professionally; work on their skills and competencies, as well as to stay up-to-date within the world of educations.

In this way, the following recommendations can be suggested:

1. to identify the strategic plan of increasing the competitiveness of a HEl by paying attention to the quality of teaching;

2. to facilitate parents and students of HEls with high education quality by the constant monitoring of their needs and adapting them to the teaching process;

3. to increase teachers' motivation to conduct research by encouraging and rewarding with bonuses and certificates, which could help in developing a successful career;

4. to organize in-university professional trainings for teachers who are interested in research, explaining them more on the peculiarities and benefits of doing research in teaching;

5. to strengthen the material and technical base of a HEl;

6. to improve various forms of professional development of teachers

7. to activate innovative processes in education in a HEl;

\section{Conclusion}

As it can clearly be noticed, today, educational quality is one of the keys to improve a HEl's competitiveness. The present study's results have shown that students of KazUIR\&WL and their parents understand educational quality almost from the same perspective, with a slight difference in two aspects: university's reputation (none of the students considers this aspect crucial, while $11 \%$ of parents think it's important) and administration work (for students it seems to be more important that for their parents). At the same time, most of the responders consider high teaching quality as an important indicator of a successful university. Whereas, the survey among the teachers of KazuIR\&WL has shown that most of the responders are quite familiar with the theory of conducting a research, but rather struggle with its implementation in real life.

\section{Declarations}

\section{Acknowledgement}

The present research is supported by the head of Basic Department of International Relations and the Center of Language Preparation of KazUIR\&WL.

\section{References}

Activities for Teaching Creativity and Problem Solving Arthur B. VanGundy, ISBN: 978-0-787-97673-6 November 2004 Pfeiffer 416 Pages. Retried from: https://www.wiley.com/en am/101+Activities+for+Teaching+Creativity+and+Problem+Solving-p-9780787976736

Badley G. \& Habeshaw T. (1991). The Changing Role of the Teacher in Higher Education, Journal of In-Service Education, 17:3, 212-218, D0I: $10.1080 / 0305763910170307$

BBC News. (15 September, 2014). What makes a global top 10 university?By Sean Coughlan. BBC News education correspondent. Retrieved from: https://www.bbc.com/news/business-29086590

British Educational Research Association. (2014). The role of research in teacher education: Reviewing the evidence,

Crystal, D. (2006). Language and the Internet. Cambridge University Press. ISBN: 978-0521868594,

Prix : 34,10 €, 318 pages. https://doi.org/10.4000/lexis.1831

DeWitt, P. (2019). 4 Reasons Educators Use Research and 4 Reasons They Don't, Finding Common Ground, Education Week

Dima A, Vasilache S, Ghinea V, Agoston S. (2013). A model of academic social responsibility. Transylvanian Review of Administrative Sciences. 2013;9(38):2343

Forbes. (Aug 10, 2009). What Makes A University Great? Retrieved from: https://www.forbes.com/2009/08/10/world-class-best-university-ranking-world-bankopinions-colleges-salmi.html?sh=44b0c08a1fc2 
Funda D (2008) Potpuno upravljanje kvalitetom u obrazovanju. Kigen, Zagreb, p.9,13

Galskova N. D. (2006). The Theory of Teaching Foreign Languages: Linguodidactics and Methodology, M., "Academia"

Hasanal, M. Zh. (2010). 10 Characteristics of a Language. English Finders. Retrieved from: https://neoenglish.wordpress.com/2010/12/16/characteristicsand-features-of-language/

Kireeva, N., Slepenkova, E., Shipunova, T. \& Iskandaryan, R. (2018). Competitiveness of higher education institutions and academic entrepreneurship, Espacios. Revista Retrieved from: https://www.revistaespacios.com/a18v39n23/18392315.html

Kunanbayeva, S. S. (2005). Modern foreign language education:methodology and theory, Hertfordshire Press Ltd, UK, 2013, 63. Retrieve from: https://www.twirpx.com/file/1572086/

Kunanbayeva, S. S. (2010). The theory and practice of the modern foreign language education, Hertfordshire Press Ltd, UK, 2013, 344. Retrieved from: https://www.twirpx.com/file/1572086/

Leko-Šimić, Mirna \& Štimac, Helena. (2012). Competitiveness in Higher Education: a Need for Marketing Orientation and Service Quality. Economics and Sociology. 5. 23-34. 10.14254/2071-789X.2012/5-2/2.

MacLellan, P. (2016). Why don't teachers use education research in teaching? Education in chemistry. Royal society of chemistry. Retrieved from: https://edu.rsc.org/analysis/why-dont-teachers-use-education-research-in-teaching/2010170.article

National ranking of the best universities of Kazakhstan. (2020). Printable version. Retrieved from: https://egov.kz/cms/en/articles/2Fbestuniinkz30

Obuhov A. S. (2006). The development of research activity of learners, Prometey, 6

Polet, J. (January 4, 2018). Universities should stop acting like corporations PHILANTHROPY DAILY

Požarnik, B. (2009). Improving the quality of teaching and learning in higher education through supporting professional development of teaching staff. Napredak. 150. 341-259

Ramos, E., Llinás-Audet, X. \& Barrena Martinez, J. (2017). Universities as Corporate Entities: The Role of Social Responsibility in Their Strategic Management. 10.5772/intechopen.69931

Salleh, H. (2020). Signteach. Why should teachers do research? Policy \& Leadership Studies Academic Group

Sayabek, Ziyadin \& Serikbekuly, Askhat. (2020). Internet-Marketing in the Sphere of Higher Education. 10.1007/978-3-030-27015-5_35.

Sherif A. Watson. (2013). Why Do Teacher Research Anyway? Teacher Inquirer, Santa Clara Elementary School

Slastenin, V. A. (2002). Pedagogy: A Handbook for the Students of Higher Educational Institutions. Moscow, "Academia", 576

Whitman, G. \& Kelleher, I. (2017). Teachers Are Researchers Spring. Retrieved from: https://www.Teachers Are Researchers Spring 2017 By Glenn Whitman and lan Kellehernais.org/magazine/independent-school/spring-2017/teachers-are-

researchers/\#: :text=Teachers\%20are\%20researchers.,decisions\%20based\%20on\%20this\%20data.\&text=All\%20this\%20data\%20could\%2C\%20however,the\%2।

\section{Figures}

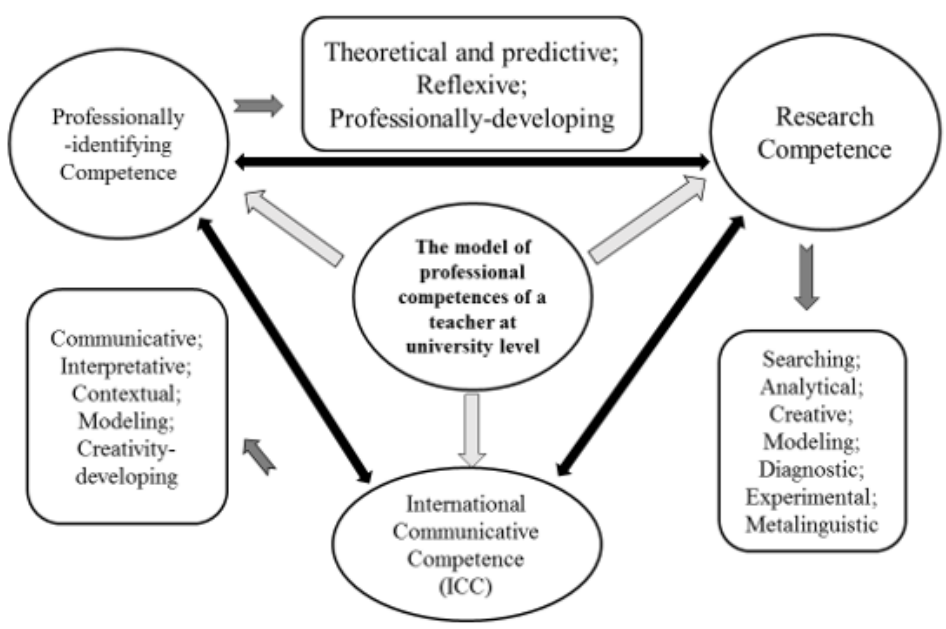

Figure 1 
Research competence, which implies searching, analytical, creative, modeling, diagnostic, experimental and metalinguistic subcompetences

\begin{tabular}{|c|r|}
\hline Ability to analyze the current \\
situation in education
\end{tabular}

\section{Figure 2}

sub-competences of Research competence

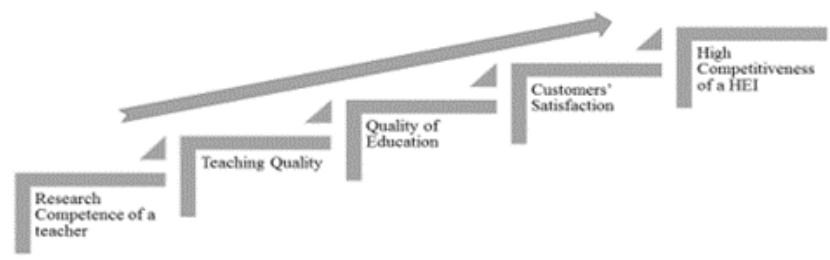

\section{Figure 3}

level of competitiveness of a university

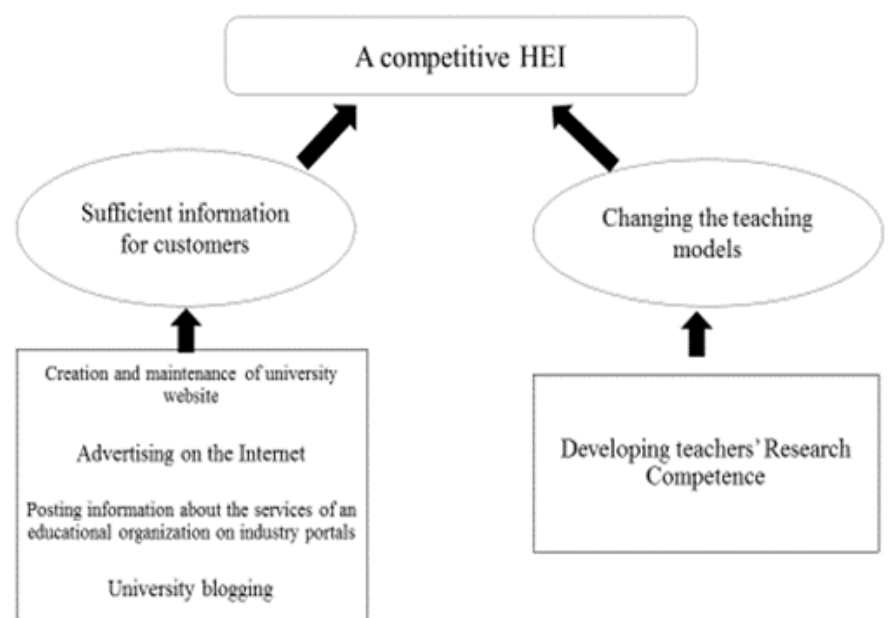

Figure 4

models of teaching 


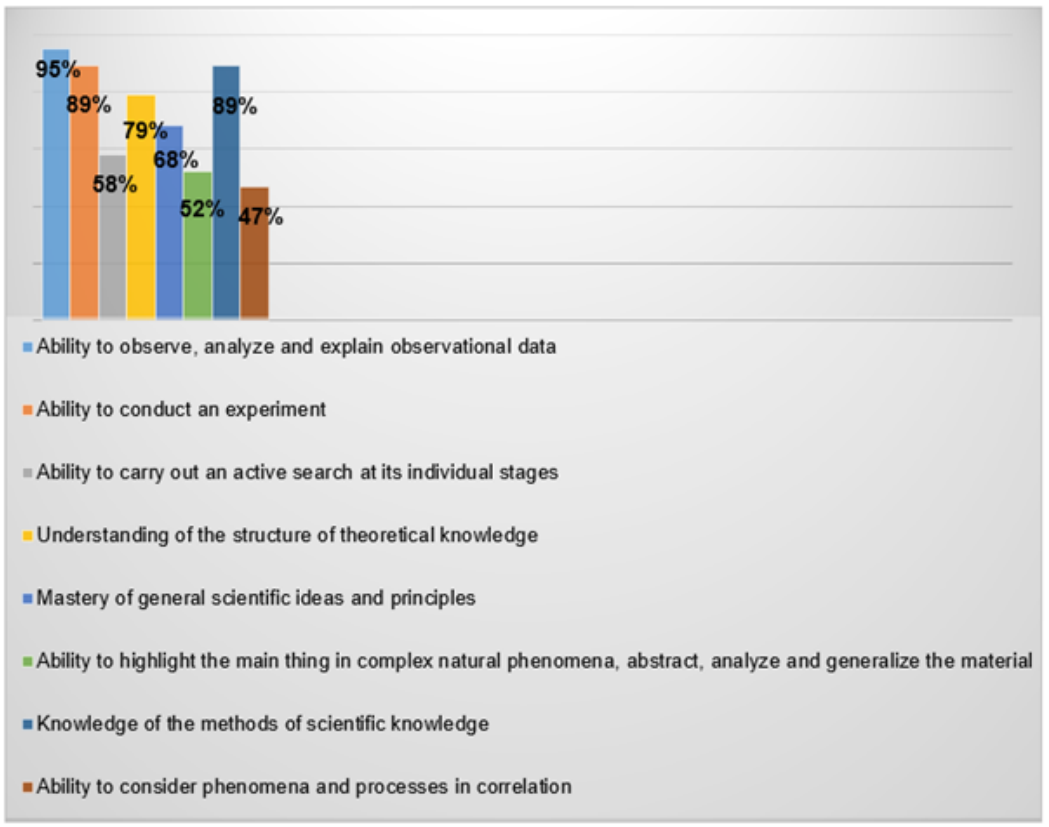

\section{Figure 5}

Diagram 1. General results of the survey for teachers 